\title{
Distribution, Molecular Structure and Functional Analysis of Carnitine Transporter (SLC22A5) in Canine Lens Epithelial Cells
}

\author{
Hideharu OCHIAI ${ }^{1)^{*}}$, Nobuyuki KANEMAKI ${ }^{2)}$, Reiichiro $\mathrm{SATO}^{3)}$, and Ken ONDA ${ }^{3)}$ \\ 1) Research Institute of Biosciences, Azabu University, 1-17-71 Fuchinobe, Chuo-ku, Sagamihara, Kanagawa \\ 252-5201, Japan \\ 2) Animal Teaching Hospital, Azabu University, Japan \\ ${ }^{3)}$ Laboratory of Internal Medicine 3, Azabu University, School of Veterinary Medicine, Japan
}

\begin{abstract}
While carnitine has been reported to have an anti-oxidative role on the ocular surface, there has been no report on the existence of a carnitine transporter (SLC22A5) in the lens. Therefore, we investigated the carnitine transport activity of canine lens epithelial cells (LEC) and determined the molecular structure of canine SLC22A5. The carnitine transport activity was $7.16 \pm 0.48 \mathrm{pmol} /$ $\mathrm{mg}$ protein $/ 30 \mathrm{~min}$. Butyrobetaine, the analogue of carnitine, reduced $30 \%$ of the activity at $50 \mu \mathrm{M}$. A coding sequence of canine carnitine transporter was $1694 \mathrm{bp}$ long and was predicted to encode 557 amino acid polypeptides. The deduced amino acid sequence of canine carnitine transporter showed $>80 \%$ similarity to that of mouse and human. Western blot analysis detected the band at $60 \mathrm{kDa}$ in the membrane of lens epithelial cells. The high content of carnitine in the lens is possibly transported from aqueous humor by SLC22A5.
\end{abstract}

Key words: carnitine, cataract, lens epithelial cells, oxidative stress, SLC22A5

\section{Introduction}

Many amino acid transport systems are distinguished based on differences in their substrate-selectivity, iondependence, $\mathrm{pH}$ sensitivity, and kinetics and regulatory properties, using membrane vesicle preparation or cultured cells $[3,4]$. The carnitine (3-hydroxy-4- $N$-trimethylaminobutyric acid)/organic cation transporters are classified as organic ion transporters in the subfamily of $22 \mathrm{~A}$, which belongs to the solute carrier (SLC) transporter superfamily that includes organic cation transporters (OCTs), organic anion transporters (OATs) and carnitine/organic cation transporters (OCTNs). OCTNs are unique in recognizing twitterionic carnitine as an endogenous substrate, and they also recognize various xenobiotics, mainly cationic compounds. Among them,
OCTN2 (SLC22A5) is an Na-dependent, high-affinity carnitine transporter, which maintains levels in serum by functioning as a reabsorption transporter after glomerular filtration in kidney [2, 20, 25]. Carnitine is a small, water-soluble molecule that has important physiological roles, including involvement in the $\beta$-oxidation of fatty acids by facilitating the transport of long-chain fatty acids across the mitochondrial inner membrane as their acylcarnitine esters, and modulation of intracellular CoA homeostasis [2, 20]. Carnitine deficiency causes severe pathological symptoms such as cardiomyopathy and muscle weakness [14, 24, 28, 31].

Lens epithelial cells (LECs) are the progenitors of the lens fibers in vivo and undergo a developmental transition into fiber cells of the lens cortex, a process characterized by distinct biochemical and morphologic chang- 
Table 1. Sequences of oligonucleotides used in this study

\begin{tabular}{cclc}
\hline \multicolumn{2}{c}{ Primer } & \multicolumn{1}{c}{ Sequence (5'-3') } & Expected Product (bp) \\
\hline $\begin{array}{c}\text { Oligonucleotide for cloning of canine } \\
\text { s1 }\end{array}$ & $\begin{array}{c}\text { SLC22A5 } \\
\text { anti }\end{array}$ & $\begin{array}{l}\text { GCAGCTGGAGCAGGAGAGCTG } \\
\text { AGGCGGGATGCTGTGGAGCTGAC }\end{array}$ & 1,096 \\
human SLC22A5: AK313230 & anti & CCTGGTAGCGTCAGTGCCAGCAGCAGC & \\
GSP1 (for 5'RACE) & sense & TCCATGGCCACAGCCCTCTTCCTGGGC & \\
GSP2 (for 3'RACE) & sense & CGGGGCAGCTCTCAGACAGGTTTGGCC & 321 \\
Oligonucleotide for RT-PCR transcript & anti & CCTGGTAGCGTCAGTGCCAGCAGCAGC & \\
canine $S L C 22 A 5$ & sense & ATC ACC ATC TTC CAG GAG CGA GA & 192 \\
GAPDH & GTC TTC TGG GTG GCA GTG ATG G & \\
$($ AB038240) & & &
\end{tabular}

(accession number) is indicated.

es such as the synthesis of crystallin proteins, cell elongation, loss of cellular organelles, and disintegration of the nucleus. It is generally understood that primary damage to LECs may cause abnormal differentiation of epithelial cells to lens fibers, which is eventually expressed as an opacity of lens tissues, i.e., a cataract. Notably, concentration of carnitine was reported to be highest in the lens among ocular tissues [19], and a dramatic depletion of lenticular carnitine was reported one of the early events in streptozocin-induced cataract in rat [18]. In addition, acetyl-L-carnitine, which is naturally produced by the enzyme acetyl carnitine transferase [9], prevents selenite-induced and L-buthionine-(S,R)sulfoximine-induced cataractogenesis in animal models $[6,7]$. It was reported that human corneal and conjunctival epithelia possessed distinct carnitine transport activity by SLC22A5, suggesting an osmoregulatory role of these tissues [32]. In spite of the significance of carnitine on the ocular surface, there has been no report on carnitine transport activity in LECs. Previously, we developed the canine lens epithelial cell line and reported several of its characteristics [12]. In this study, we examined the carnitine transport activity of this cell line, determined its molecular structure, and investigated the distribution of canine SLC22A5.

\section{Materials and Methods}

\section{Animal and cell samples}

All experiments were performed according to the guidelines of The Laboratory Animal Care Committee of Azabu University, and were in compliance with the Fundamental Guidelines for Proper Conduct of Animal Experiment and Related Activities in Academic Research
Institutions. The canine lens epithelial cell line originating from mature cataract was maintained as described previously [12]. Several tissues were obtained from a 5-year-old male Japanese Shiba dog after deep anesthesia by pentobarbital.

\section{Measurement of carnitine transport activity}

Radioactive $\left({ }^{3} \mathrm{H}-\right)$ carnitine was purchased from American Radiolabeled Chemicals (St Louis, MO, USA). Carnitine uptake was measured as described previously [16]. Simply, the cells were plated in $5 \times 10^{5}$ cells/ 6 -well plate $24 \mathrm{~h}$ before the experiment. After washing the cells, the medium containing $100 \mu \mathrm{M}$ carnitine with radioisotope $(185 \mathrm{kBq} / \mathrm{ml})$ was added and incubated at $37^{\circ} \mathrm{C}$. To study the effect of butyrobetaine, the analogue of carinitine, on transport activity, $50 \mu \mathrm{M}$ butyrobetaine was included in an incubation medium containing radio-labeled carnitine. Uptake was terminated by washing with ice-cold phosphate-buffered saline. After solubilizing the cells with $1 \%$ SDS, the radioactivity was measured with a liquid scintillation counter and protein content was determined by Micro BCA method.

\section{Determination of cDNA sequence of canine carnitine transporter}

The cDNA sequence of canine carnitine transporter was determined as described previously [15]. Briefly, total RNA from the lens epithelial cell line was isolated using an RNA extraction solution (Isogen, Nippon Gene, Tokyo, Japan). The primers used in this study are shown in Table 1. The primer set ( $\mathrm{s} 1$ and a1) for the amplification of a partial canine SLC22A5 cDNA was prepared from the conserved region sequences between humans and mice (DDBJ accession No. AK313230 and 


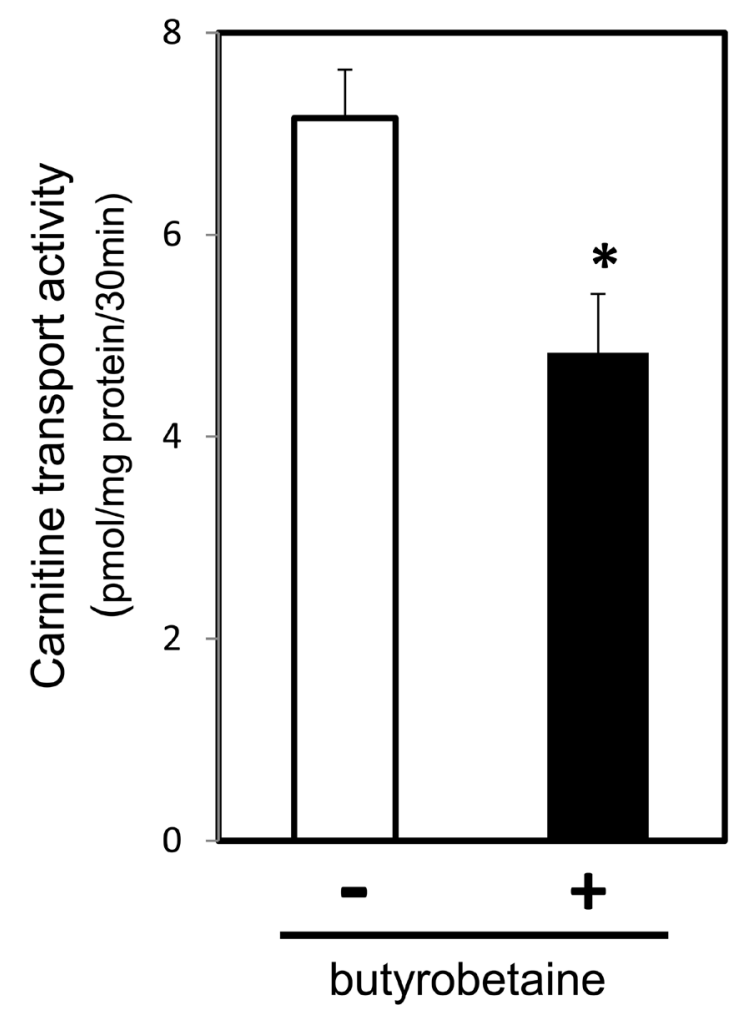

Fig. 1. Carnitine transport activity of LEC in the presence (closed column) or absence (open column) of $50 \mu \mathrm{M}$ butyrobetaine. The experiment was performed in triplicate using 6-well plates. The values are means and SD of 4 individual experiments. Statistical analysis was performed by use of Welch's $t$ test. The criterion significance was taken to be $P<0.05$ (*).

BC031118, respectively). RT-PCR amplification was performed employing a SuperscriptIII first cDNA system kit (Invitrogen, Carlsbad, CA, USA) with Hot start Ex Taq DNA polymerase (Takara Bio, Otsu, Japan). The band was excised from the agarose gel and purified using a Wizard SV gel clean-up system (Promega, Tokyo, Japan). The extracted and purified DNA was cloned into a pCR II-TOPO cloning vector (Invitrogen) and sequenced with a BigDye terminator kit ver.3 (Applied Biosystems, Carlsbad, CA, USA). The nucleotide sequence obtained exhibited high similarities ( $>85 \%$ ) to human SLC22A5 cDNA sequences. In order to determine the $3^{\prime}$ and $5^{\prime}$ regions of cDNA, RACE methods were carried out using a SMARTer RACE cDNA amplification kit (Clontech, Mountain View, CA, USA) and a set of canine SLC22A5 gene-specific primers (GSP1 and GSP2).
RT-PCR analysis of carnitine $m R N A$ in canine tissues

In order to examine the expression of carnitine transporter mRNA in various organs of a dog, we performed RT-PCR using newly designed primers specific to canine carnitine transporters (GSP1 and GSP2: Table 1). RTPCR conditions for $S L C 22 A 5$ were as follows: 35 cycles of three steps; $94^{\circ} \mathrm{C}$ for $15 \mathrm{sec}, 68^{\circ} \mathrm{C}$ for $15 \mathrm{sec}$, and $72^{\circ} \mathrm{C}$ for $20 \mathrm{sec}$, while conditions for GAPDH were 30 cycles of three steps; $94^{\circ} \mathrm{C}$ for $15 \mathrm{sec}, 60^{\circ} \mathrm{C}$ for $15 \mathrm{sec}$, and $72^{\circ} \mathrm{C}$ for $20 \mathrm{sec}$ with Hot start Ex Taq DNA polymerase.

\section{Western blot analysis}

To investigate the expression of carnitine transporter protein in the membrane, anti-canine $S L C 22 A 5$ serum was prepared with the peptide antigen designed according to a C-terminus amino acid sequence of canine carnitine transporter (Fig. 3. amino acid 537-550, CGHTRMLKDSEDSSI). Peptide conjugated with keyhole limpet hemocyanin (KLH) was purchased from the laboratory of Operon (Tokyo, Japan). Anti-canine carnitine transporter serum was purified by passage over an affinity column of the peptide antigen. Cell membranes of the tissues for Western blot analysis were prepared as reported by Denker et al. [5]. In brief, the cells were homogenized at $4^{\circ} \mathrm{C}$ in a buffer containing $0.1 \mathrm{M} \mathrm{KCl}, 5 \mathrm{mM} \mathrm{Na}_{2} \mathrm{HPO}_{4} \mathrm{pH} 7.5,0.75 \mathrm{mM} \mathrm{Na}-$ EGTA pH 7.5, $1 \mathrm{mM}$ DTT, $5 \mathrm{mM} \mathrm{MgCl}_{2}, 200 \mu \mathrm{g} / \mathrm{ml}$ phenylmethylsulfonyl fluoride, and $4 \mu \mathrm{g} / \mathrm{ml}$ leupeptin. Homogenates were centrifuged for $10 \mathrm{~min}$ to remove debris. The $1 \mathrm{ml}$ supernatant was laid over a $5 \mathrm{ml}$ sucrose solution containing $0.8 \mathrm{mM}$ sucrose and $2 \mathrm{mM}$ Na-EGTA, and was centrifuged at 32,000 g for $40 \mathrm{~min}$. Protein concentration of the pellet was determined by the BCA method, and was used for Western blot analysis as previously described [15]. The membrane-rich fraction was simply solubilized, electrophoresed into $12 \%$ polyacrylamide gels, and immunoblotted with a chemiluminescence autoradiograph. The membranerich fraction was then treated with a primary antibody against C-terminus of canine $S L C 22 A 5$, followed by a secondary antibody (anti-rabbit $\mathrm{IgG}(\mathrm{H}+\mathrm{L})$ goat $\mathrm{IgG}$ Fab' HRP, $\times 20,000$, Seikagaku Corp., Tokyo, Japan). The SLC22A5 protein was detected with an ECL plus a chemiluminescence detection system (GE Healthcare Bioscience, Chalfont, UK) and exposed to an x-ray film. To test the specificity of anti-serum, $1 \mathrm{ml}$ of the purified anti-serum was absorbed with $1 \mathrm{mg}$ of the peptide (C-GHTRMLKDSEDSSI) at $4{ }^{\circ} \mathrm{C}$ over night. 


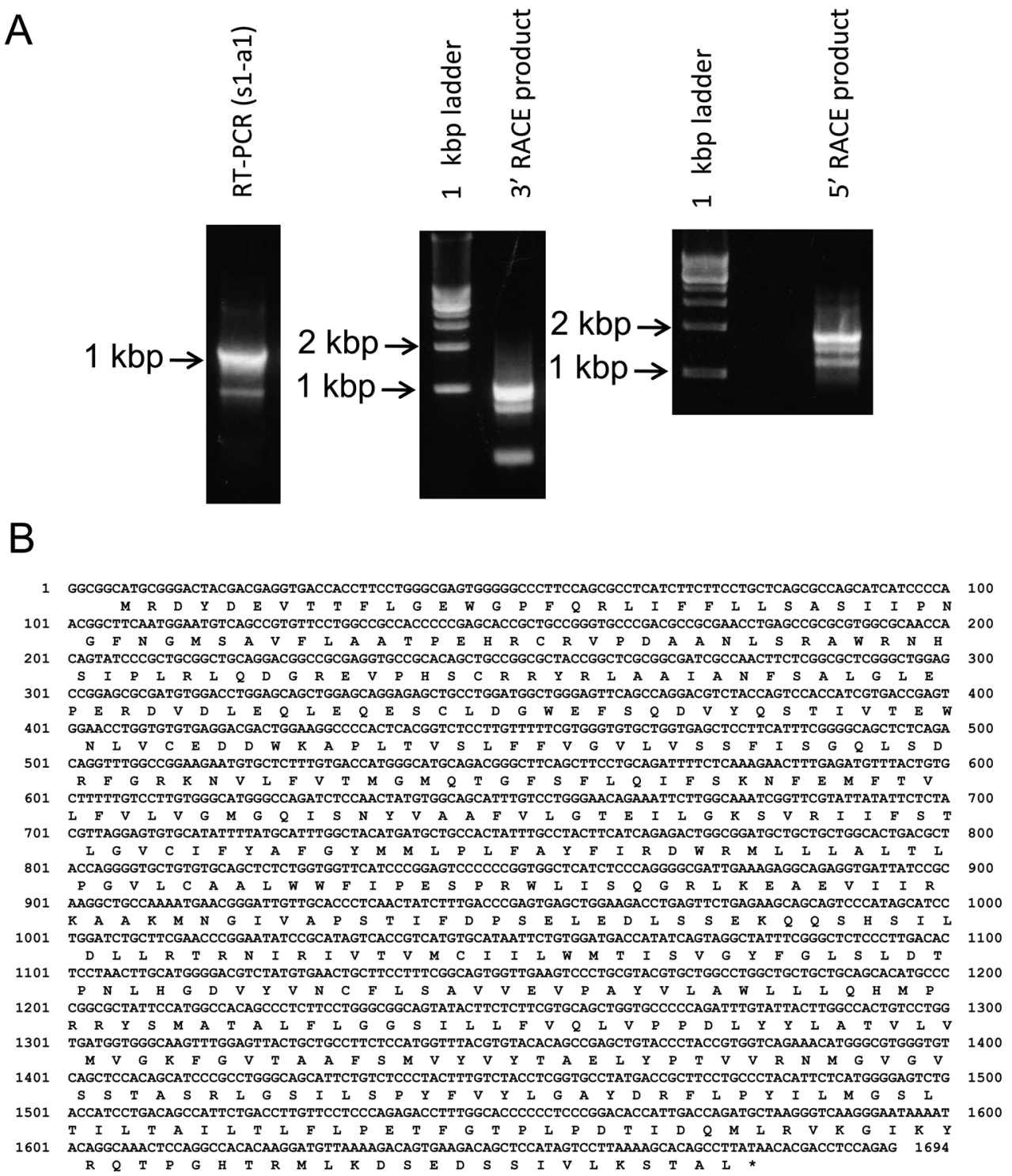

Fig. 2. PCR-based cloning of 5'- and 3 '-stretched cDNA clones for canine carnitine transporter (A). Electrophoresis of RT-PCR products of canine SLC22A5 using primers (s1 and a1) well conserved between humans and rodents (A) (left). 5'and 3' RACE products with the primers shown in Table 1 (right). Nucleotide and deduced amino acid sequence of canine are shown (B). Full-length canine carnitine transporter cDNA was $1694 \mathrm{bp}$ in length and contained an entire open reading frame of $1671 \mathrm{bp}$, encoding canine carnitine transporter of 557 amino acids. The termination codon is asterisked.

This pre-absorbed anti-serum was also used for Western blot analysis.

\section{Results}

Carnitine transport activity of the canine lens epithelial cell line as indicated in Fig. 1. The transport activity was $7.16 \pm 0.48 \mathrm{nmol} / \mathrm{mg}$ protein $/ 30 \mathrm{~min}$, while the presence of $50 \mu \mathrm{M}$ butyrobetaine, the specific inhibitor of carnitine transporter, reduced transport activity by $30 \%$. Figure 2 shows the electrophoresis of RT-PCR products of canine carnitine transporters using primers (s1 and a1), that were well-conserved between human and rodent. The nucleotide sequence comprising 1,096 bp showed high similarities to rat carnitine cDNA sequences. The primers used for RACE were prepared from the sequence details listed in Table 1. An obtained nucleotide sequence corresponding to a full-length canine carnitine 


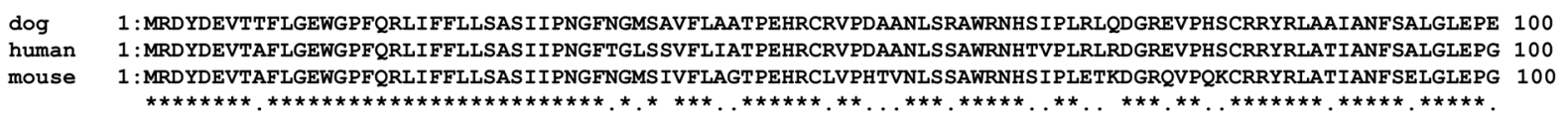

dog 101:RDVDLEQLEQESCLDGWEFSQDVYQSTIVTEWNLVCEDDWKAPLTVSLFFVGVLVSSFISGQLSDRFGRKNVLFVTMGMQTGFSFLQIFSKNFEMFTVLF 200 human 101: RDVDLGQLEQESCLDGWEFSQDVYLSTIVTEWNLVCEDDWKAPLTISLFFVGVLLGSFISGQLSDRFGRKNVLFVTMGMQTGFSFLQIFSKNFEMFVVLF 200 mouse 101 : RDVDLEQLEQESCLDGWE YDKDVFLSTIVTEWDLVCKDDWKAPLTTSLFFVGVLMGSFISGQLSDRFGRKNVLFLTMGMQTGFSFLQVFSVNFEMFTVLF 200

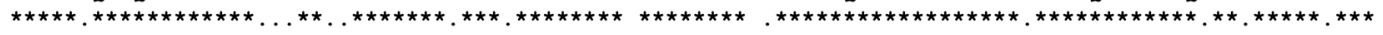

dog 201 :VLVGMGQISNYVAAFVLGTEILGKSVRIIFSTLGVCIFYAFGYMMLPLFAYFIRDWRMLLLALTLPGVLCAALWWFIPESPRWLISQGRLKEAEVIIRKA 300 human 201 : VLVGMGQISNYVAAFVLGTEILGKSVRI IFSTLGVCIFYAFGYMVLPLFAYFIRDWRMLLVALTMPGVLCVALWWFIPESPRWLISQGRFEEAEVIIRKA 300 mouse 201 : VLVGMGQISNYVAAFVLGTEILSKSIRI IFATLGVCIFYAFGFMVLPLFAYFIRDWRMLLLALTVPGVLCGALWWFIPESPRWLISQGRIKEAEVIIRKA 300

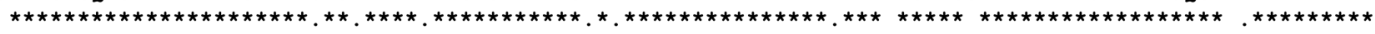

dog 301 : AKMNG IVAPSTIFDPSELEDLSSEKOOSHSILDLLRTRNIRIVTVMCIILWMTISVGYFGLSLDTPNLHGDVYVNCFLSAVVEVPAYVLAWLLLOHMPRR 400 human 301: AKANGIVVPSTIFDPSELQDLSSKKQQSHNILDLLRTWNIRMVTIMS IMLWMTISVGYFGLSLDTPNLHGDIFVNCFLSAMVEVPAYVLAWLLLQYLPRR 400 mouse 301: AKINGIVAPSTIFDPSELQDLNSTKPQLHHIYDLIRTRNIRVITIMSIILWLTISVGYFGLSLDTPNLHGDIYVNCFLLAAVEVPAYVLAWLLLQYLPRR 400

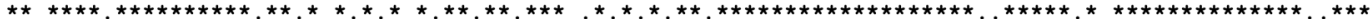

dog 401 :YSMATALFLGGSILLFVQLVPPDLYYLATVLVMVGKFGVTAAFSMVYVYTAELYPTVVRNMGVGVSSTASRLGSILSPYFVYLGAYDRFLPYILMGSLTI 500 human 401 : YSMATALFLGGSVLLFMQLVPPDLYYLATVLVMVGKFGVTAAFSMVYVYTAELYPTVVRNMGVGVSSTASRLGSILSPYFVYLGAYDRFLPYILMGSLTI 500 mouse 401:YSISAALFLGGSVLLFMOLVPSELFYLSTALVMVGKFGITSAYSMVYVYTAELYPTVVRNMGVGVSSTASRLGSILSPYFVYLGAYDRFLPYILMGSLTI 500

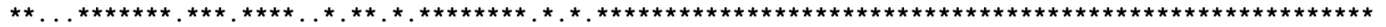

dog 501 : LTAILTLFLPETFGTPLPDTIDQMLRVKGIKYRQTPGHTRMLKDSEDSSIVLKSTAL human 501 : LTAILTLFLPESFGTPLPDTIDQMLRVKGMKHRKTPSHTRMLKDGQERPTILKSTAF mouse 501: LTAILTLFFPESFGVPLPDTIDQMLRVKGIKQWQIQSQTRMQKDGEESPTVLKSTAF 557

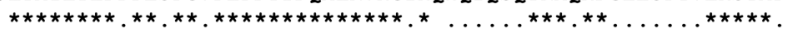

Fig. 3. Amino acid sequences of canine $S L C 22 A 5$ were compared with those of human and mouse. Multiple sequence alignments were performed using the Genetyx program (ver. 10). Asterisks and dots indicate identical residues and conservative substitutions, respectively. Amino acid sequence used for preparation of anti-canine SLC22A5 serum was overlined.

transporter cDNA was 1,719 bp in length (DDBJ accession number AB923814) and contained an entire open reading frame of $1,671 \mathrm{bp}$, encoding a canine carnitine transporter of 557 amino acids and having a theoretical mass of $63 \mathrm{kDa}$ (Fig. 2B). Comparison of cDNA sequence of obtained in this study and Genbank XM_855641 (putative canine SLC22A5) indicated the difference in 3 nucleotide (nt945, 949 and 951) and 1 amino acid (aa315: phenylalanine and serine). Figure 3 shows a comparison of a canine carnitine transporter with those reported from humans and rodents. The deduced amino acid sequence of the carnitine transporter showed very close similarities of $82 \%$ to those of mouse and human. RT-PCR analysis of carnitine transporter expression in various canine tissues is indicated in Fig. 4. A single distinct band was observed in all the samples examined. Western blot analysis using antiserum against C-terminus of canine carnitine transporter detected a band at $60 \mathrm{kDa}$ in the LEC (Fig. 5). This band disappeared when a primary antibody was pre-absorbed with C-terminus peptides.

\section{Discussion}

Cataracts are one of the most significant ophthalmologic diseases in veterinary medicine. It is well-under- stood that dogs are more prone to develop cataracts than other domestic animals.

The lens undergoes major oxidative stress because it is constantly exposed to light and oxidants [23, 27, 29]. The first line of defense against oxidation stress is constituted by radical scavenging antioxidants that reduce the oxidative insult. For example, glutathione, ascorbic acid and taurine, which are all highly represented in lens tissue, exert protective effects in an in vitro model of a diabetic cataract $[11,21,30]$. Among ocular tissues, carnitine was highest in the lens [19], and the carnitine level of lenses with deep opacification was lower than that of a normal lens, suggesting its protective role in the development of cataract [8]. In fact, carnitine protected against damage produced by gamma radiation by increasing the activity of the enzyme super oxide dismutase, and by scavenging free radicals that were generated by ionizing radiation [13]. While carnitine has been reported to have an anti-oxidative or anti-radical role in the ocular surface, there has not been a report on the evidence of the existence of carnitine transporter in lens.

In this study, we conducted a functional analysis of carnitine transport activity in LECs and revealed the certain butyrobetaine-sensitive components of carnitine transport activities. We determined a full-length cDNA sequence of canine SLC22A5 based on a conserved 


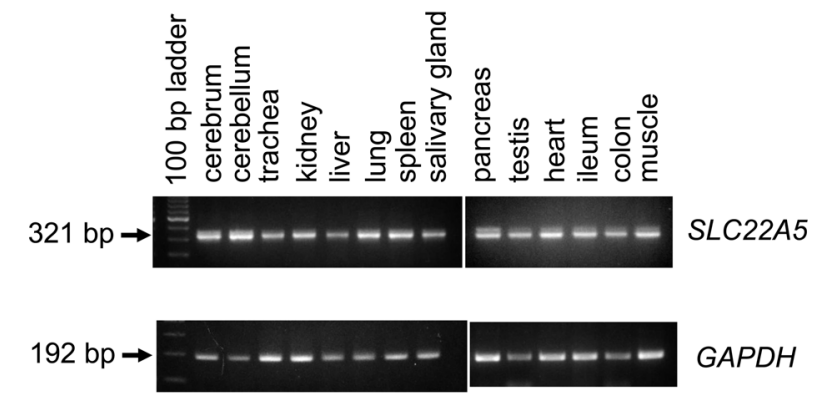

Fig. 4. RT-PCR analysis of mRNA of canine $S L C 22 A 5$ in various dog tissues (A). Integrity of RNA was examined by glyceraldehyde-3-phosphate dehydrogenase $(G A P D H)$.

cDNA sequence among mammalians. The deduced amino acid sequence of canine SLC22A5 showed high similarities to those of human and mouse. RT-PCR analysis confirmed that carnitine transporter was detected all tissues examined. Expression of human $S L$ $C 22 A 5$ was reported to be ubiquitous, but it was more so in kidney, muscle, and heart, and less so in pancreas, liver, lung, brain, and small intestine, by Northern blot analysis [26]. Precise evaluation of canine SLC22A5 may be necessary using Real-time RT-PCR analysis. Butyrobetaine reduced only $30 \%$ of the carnitine transport activity of LEC. There was reportedly other carnitine transporters, for example SLC22A16 [1]. Therefore, other carnitine transporters may possibly exist in LECs. While the canine cDNA sequence that possessed high homology with SLC22A5 was clarified in this study, there is no evidence of this putative canine $S L C 22 A 5$ transport carnitine. Next, we will examine the functional analysis of canine $S L C 22 A 5$ by transfection study.

Recently, Peluso et al. reported that carnitine safeguarded the chaperone activity of $\alpha$-crystallin, which prevents protein aggregation in the lens by decreasing the protein posttranslational modifications induced by oxidative stress [17]. Posttranslational modifications of crystallin, consequent to aging or diabetes, resulted in conformational changes and aggregation of the proteins and led to lens opacification [10]. As the fluid of the ocular surface contains certain a level of carnitine [22], carnitine in lens may possibly be transported by $S L$ $C 22 A 5$ from aqueous humor to protect crystallins from oxidative stresses. In summary, we revealed the carnitine transport activity in LECs, determined the molecular structure of canine $S L C 22 A 5$, and investigated its distribution in several tissues. To our knowledge, this is the

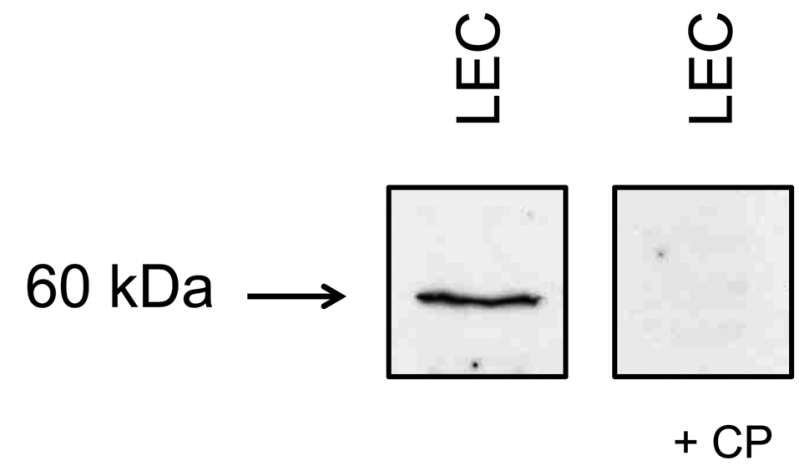

Fig. 5. Western blot analysis of $S L C 22 A 5$ expression using antiserum against the C-terminus of canine $S L C 22 A 5$ peptides. $\mathrm{CP}$ represents antiserum pre-absorbed with its corresponding antigenic peptides.

first report on carnitine transport activity in LECs. The data in this paper may facilitate the study of the carnitine metabolism and the function in lens.

\section{Acknowledgments}

This study was supported in part by a Grant-in-aid to HO from the Ministry of Education, Culture, Sports, Science and Technology of Japan (No. 19580376), and by a research project grant awarded by the Azabu University Research Services Division.

\section{References}

1. Aouida, M., Poulin, R., and Ramotar, D. 2010. The human carnitine transporter SLC22A16 mediates high affinity uptake of the anticancer polyamine analogue bleomycin-A5. $J$. Biol. Chem. 285: 6275-6284. [Medline] [CrossRef]

2. Bremer, J. 1983. Carnitine-metabolism and functions. Physiol. Rev. 63: 1420-1480. [Medline]

3. Christensen, H.N., Handlogten, M.E., Lam, I., Tager, H.S., and Zand, R. 1969. A bicyclic amino acid to improve discriminations among transport systems. J. Biol. Chem. 244: 1510-1520. [Medline]

4. Christensen, H.N. 1990. Role of amino acid transport and countertransport in nutrition and metabolism. Physiol. Rev. 70: 43-77. [Medline]

5. Denker, B.M., Smith, B.L., Kuhajda, F.P., and Agre, P. 1988. Identification, purification, and partial characterization of a novel $\mathrm{Mr}$ 28,000 integral membrane protein from erythrocytes and renal tubules. J. Biol. Chem. 263: 15634-15642. [Medline]

6. Elanchezhian, R., Sakthivel, M., Geraldine, P., and Thomas, P.A. 2010. Regulatory effect of acetyl-1-carnitine on expression of lenticular antioxidant and apoptotic genes in seleniteinduced cataract. Chem. Biol. Interact. 184: 346-351. [Med- 
line] [CrossRef]

7. Elanchezhian, R., Sakthivel, M., Isai, M., Geraldine, P., and Thomas, P.A. 2009. Evaluation of lenticular antioxidant and redox system components in the lenses of acetyl-L-carnitine treatment in BSO-induced glutathione deprivation. Mol. Vis. 15: 1485-1491. [Medline]

8. Gawecki, M., Raczyńska, K., Homziuk, M., and Iwaszkiewicz-Bilikiewicz, B. 2004. [Carnitine level in human lens and density of cataract]. Klin. Oczna 106: 409-410. [Medline]

9. Goa, K.L. and Brogden, R.N. 1987. 1-Carnitine. A preliminary review of its pharmacokinetics, and its therapeutic use in ischaemic cardiac disease and primary and secondary carnitine deficiencies in relationship to its role in fatty acid metabolism. Drugs 34: 1-24. [Medline] [CrossRef]

10. Harding, J.J.1981. Changes in lens proteins in cataract. pp. 327-365, In: Molecular and Cellular Biology of the Eye Lens (Bloemendal, H., ed.) John Wiley and Sons, New York.

11. Kilic, F., Bhardwaj, R., Caulfeild, J., and Trevithick, J.R. 1999. Modelling cortical cataractogenesis 22: is in vitro reduction of damage in model diabetic rat cataract by taurine due to its antioxidant activity? Exp. Eye Res. 69: 291-300. [Medline] [CrossRef]

12. Kanemaki, N., Saito, M., Onda, K., Maruo, T., Ogihara, K., Naya, Y., Morishita, T., and Ochiai, H. 2012. Establishment of a lens epithelial cell line from a canine mature cataract. Exp. Anim. 61: 41-47. [Medline] [CrossRef]

13. Kocer, I., Taysi, S., Ertekin, M.V., Karslioglu, I., Gepdiremen, A., Sezen, O., and Serifoglu, K. 2007. The effect of L-carnitine in the prevention of ionizing radiation-induced cataracts: a rat model. Graefes Arch. Clin. Exp. Ophthalmol. 245: 588-594. [Medline] [CrossRef]

14. Nezu, J., Tamai, I., Oku, A., Ohashi, R., Yabuuchi, H., Hashimoto, N., Nikaido, H., Sai, Y., Koizumi, A., Shoji, Y., Takada, G., Matsuishi, T., Yoshino, M., Kato, H., Ohura, T., Tsujimoto, G., Hayakawa, J., Shimane, M., and Tsuji, A. 1999. Primary systemic carnitine deficiency is caused by mutations in a gene encoding sodium ion-dependent carnitine transporter. Nat. Genet. 21: 91-94. [Medline] [CrossRef]

15. Ochiai, H., Kanemaki, N., Kamoshida, S., Murakami, M., Ichihara, N., Asari, M., and Nishita, T. 2009. Determination of full-length cDNA nucleotide sequence of equine carbonic anhydrase VI and its expression in various tissues. J. Vet. Med. Sci. 71: 1233-1237. [Medline] [CrossRef]

16. Ochiai, H., Higa, K., and Fujise, H. 2004. Molecular identification of K-CL cotransporter in dog erythroid progenitor cells. J. Biochem. 135: 365-374. [Medline] [CrossRef]

17. Peluso, G., Petillo, O., Barbarisi, A., Melone, M.A., Reda, E., Nicolai, R., and Calvani, M. 2001. Carnitine protects the molecular chaperone activity of lens alpha-crystallin and decreases the post-translational protein modifications induced by oxidative stress. FASEB J. 15: 1604-1606. [Medline]

18. Pessotto, P., Liberati, R., Petrella, O., Romanelli, L., Calvani, M., and Peluso, G. 1997. In experimental diabetes the decrease in the eye of lens carnitine levels is an early impor- tant and selective event. Exp. Eye Res. 64: 195-201. [Medline] [CrossRef]

19. Pessotto, P., Valeri, P., and Arrigoni-Martelli, E. 1994. The presence of L-carnitine in ocular tissues of the rabbit. $J$. Ocul. Pharmacol. 10: 643-651. [Medline] [CrossRef]

20. Pons, R. and De Vivo, D.C. 1995. Primary and secondary carnitine deficiency syndromes. J. Child Neurol. 10:(Suppl 2): S8-S24. [Medline]

21. Rose, R.C., Richer, S.P., and Bode, A.M. 1998. Ocular oxidants and antioxidant protection. Proc. Soc. Exp. Biol. Med. 217: 397-407. [Medline] [CrossRef]

22. Siddiqi, N.J., Alhomida, A.S., Khan, H.A., and Ong, W.Y. 2012. A study on the distribution of different carnitine fractions in various tissues of bovine eye. Cell Mol. Biol. Noisyle-grand 58: 66-70. [Medline]

23. Spector, A. 1995. Oxidative stress-induced cataract: mechanism of action. FASEB J. 9: 1173-1182. [Medline]

24. Stanley, C.A., DeLeeuw, S., Coates, P.M., Vianey-Liaud, C., Divry, P., Bonnefont, J.P., Saudubray, J.M., Haymond, M., Trefz, F.K., Breningstall, G.N., et al. 1991. Chronic cardiomyopathy and weakness or acute coma in children with a defect in carnitine uptake. Ann. Neurol. 30: 709-716. [Medline] [CrossRef]

25. Tamai, I., China, K., Sai, Y., Kobayashi, D., Nezu, J., Kawahara, E., and Tsuji, A. 2001. Na(+)-coupled transport of Lcarnitine via high-affinity carnitine transporter OCTN2 and its subcellular localization in kidney. Biochim. Biophys. Acta 1512: 273-284. [Medline] [CrossRef]

26. Tamai, I., Ohashi, R., Nezu, J., Yabuuchi, H., Oku, A., Shimane, M., Sai, Y., and Tsuji, A. 1998. Molecular and functional identification of sodium ion-dependent, high affinity human carnitine transporter OCTN2. J. Biol. Chem. 273: 20378-20382. [Medline] [CrossRef]

27. Taylor, A. and Davies, K.J. 1987. Protein oxidation and loss of protease activity may lead to cataract formation in the aged lens. Free Radic. Biol. Med. 3: 371-377. [Medline] [CrossRef]

28. Treem, W.R., Stanley, C.A., Finegold, D.N., Hale, D.E., and Coates, P.M. 1988. Primary carnitine deficiency due to a failure of carnitine transport in kidney, muscle, and fibroblasts. N. Engl. J. Med. 319: 1331-1336. [Medline] [CrossRef]

29. van der Pols, J.C. 1999. A possible role for vitamin C in agerelated cataract. Proc. Nutr. Soc. 58: 295-301. [Medline] [CrossRef]

30. Varma, S.D., Chand, D., Sharma, Y.R., Kuck, J.F. Jr., and Richards, R.D. 1984. Oxidative stress on lens and cataract formation: role of light and oxygen. Curr. Eye Res. 3: 35-57. [Medline] [CrossRef]

31. Walter, J.H. 1996. L-Carnitine. Arch. Dis. Child. 74: 475478. [Medline] [CrossRef]

32. Xu, S., Flanagan, J.L., Simmons, P.A., Vehige, J., Willcox, M.D., and Garrett, Q. 2010. Transport of L-carnitine in human corneal and conjunctival epithelial cells. Mol. Vis. 16: 1823-1831. [Medline] 